\title{
Zastupljenost i obrada antropomorfnih i zoomorfnih frazema u Rusko-hrvatskome frazeološkom rječniku (2019)
}

\begin{abstract}
Barčot Branka, Zastupljenost $i$ obrada antropomorfnih i zoomorfnih frazema $u$ Rusko-hrvatskome frazeološkom rječniku (2019) (Representation and Anatomy of Anthropomorphic and Zoomorphic Dictionary Entries in the Russian-Croatian Phraseological Dictionary [2019]). "Poznańskie Studia Slawistyczne" 20. Poznań 2021. Publishing House of the Poznań Society for the Advancement of the Arts and Sciences, Adam Mickiewicz University, pp. 107-121. ISSN 2084-3011.
\end{abstract}

This paper presents the analysis of Russian animalistic phraseological units included in the Russian-Croatian Phraseological Dictionary (2019). In our research we focused on etalons that have the simile structure. Anthropomorphism and zoomorphism are two antipodes of the same reality within the language picture of the world - in our case it is the Russian language picture of the world. We believed that the anthropocentric perspective of the animal world was stronger than the ecocentric perspective, and that it has influenced the Russian language correspondingly, which has led us to the conclusion that there must be more Russian anthropomorphic similes than zoomomorphic similes. But the analysis that we have performed within the frames of the Russian-Croatian Phraseological Dictionary has not proven our hypothesis. The findings of this study suggest that there is an equal number of anthropomorphic and zoomorphic similes within the analyzed phraseological material.

Keywords: Anthropomorphic Phraseological Units; Zoomorphic Phraseological Units; RussianCroatian Phraseological Dictionary; Language Picture of the World; Linguoculturology

\section{Uvod}

Pitanjima položaja životinja u ljudskoj kulturi i utjecaja ljudske kulture na egzistenciju životinjskih vrsta i jedinki bavi se kulturna zoologija, koja se u Hrvatskoj razvija od 90-ih godina prošloga stoljeća. Nikola Visković, pionir kulturne zoologije u nas, smatra da početak spoznajnih sinteza o ulogama animalnog u kulturnoj historiji tek treba doći (Visković, 
2009, 11), a trebao bi se dogoditi onda kada se napusti antropocentrični pristup prirodi, čemu bi svakako trebala prethoditi odgojna, upravna i pravna prevencija i sankcija svih oblika ponašanja koja su protivna i pogubna za životinje.

S obzirom na činjenicu da je čovjek tijekom evolutivnog razvoja uvijek bio na neki način vezan za životinje, razumljivo je da se ta povezanost manifestirala u jeziku, a samim time i u jezičnoj slici svijeta, odnosno u naivnoj slici svijeta, kako ju naziva ruski lingvist Jurij D. Apresjan ${ }^{1}$, uzimajući pri tome u obzir predznanstveni karakter jezične slike svijeta. Za razliku od konceptualne slike svijeta, koja je konstantno podložna promjenama, tragovi zabluda i grešaka koji nastaju prilikom čovjekove spoznaje svijeta dugo se čuvaju u jezičnoj slici svijeta (Маслова, 2001, 65). Upravo jezična slika svijeta oblikuje tip odnosa čovjeka prema prirodi, prema životinjama, a u konačnici i prema samome sebi. Napomenimo i da je jezična slika svijeta za svaki jezik različita, a jezične ličnosti imaju obvezu oblikovati sadržaj svojih iskaza u skladu s određenom jezičnom slikom svijeta. S jezičnom su slikom svijeta u izravnoj vezi i pojmovi antropomorfizam i zoomorfizam, dva antipoda iste stvarnosti: zoomorfizam označava životinjsko u ljudskom, a antropomorfizam pokazuje ljudsko u životinjskom. Postavlja se pitanje je li etologija, znanost koja se bavi ponašanjem i svijesti životinja, uopće ostavila traga u jezičnoj slici svijeta ili su zastupljene samo izravne posljedice antropocentričnog pristupa prirodi (tu ponajprije imamo u vidu antropomorfne frazeme). Tim ćemo se pitanjem pozabaviti u daljnjem tekstu, i to na odabranoj frazeološkoj građi ruskoga jezika.

Upravo su aspekti životinjskog u ljudskom te ljudskog u životinjskom tema ovoga rada, i to na frazeološkoj građi ispisanoj iz Rusko-hrvatskoga frazeološkog rječnika (RHFR) autorskog kvarteta: Željka Fink Arsovski, Valerij Mokienko, Anita Hrnjak i Branka Barčot, objavljenog koncem 2019. godine. Rječnik sadržava oko 3100 ruskih frazema i više od 4100 značenjskih ekvivalentnih frazema, kolokacija i sintagmi.

${ }^{1}$ U djelu Leksička semantika (rus. Лексическая семантика) iz 1974. godine J. D. Apresjan povezuje naivnu sliku svijeta sa značenjem riječi. Govori kako naivna slika svijeta, koja se stvara stoljećima i u koju ulaze geometrija, fizika, psihologija itd., odražava materijalno i duhovno iskustvo naroda. Tako se naivne slike svijeta, temeljene na analizi značenja riječi, mogu razlikovati u detaljima ovisno o jeziku. Primjerice, iz ruske perspektive kauč ima duljinu i širinu, a iz engleske - duljinu i dubinu (Апресян 1974, 59). 
Rad je koncipiran na način da nakon uvodnog dijela slijedi kratko objašnjenje našeg poimanja pojmova zoonim i animalizam s ciljem pojašnjenja principa prikupljanja frazeološke građe iz RHFR. Središnji dio rada posvećen je analizi etalona iz jezične slike svijeta govornika ruskoga jezika, nastalih kao odraz antropomorfizma i zoomorfizma, a upotrebom kojih dolazi do sterotipiziranja životinja uključenih u analizirane etalone. Nakon analize donosi se objašnjenje strukture rječničkih članaka analiziranih etalona. Treba svakako naglasiti da se zaključci o percepciji zastupljenih životinja temelje isključivo na ekscerpiranoj frazeološkoj građi te imaju, dakako, ograničenja. Cilj je ovoga rada pokazati do koje se mjere tragovi antropocentričnog pristupa fauni fiksiraju u frazeološkoj građi ruskoga jezika, odnosno konkretno u etalonima koji imaju oblik poredbenih frazema. Okviri našeg istraživanja zadani su okvirima RHFR.

\section{O razgraničenju pojmova zoonim i animalizam}

U hrvatskoj se frazeologiji ustalila upotreba pojma zoonim za označavanje naziva životinjske sastavnice frazema, dok je u suvremenoj onomastici, koja razlikuje ime i naziv, zoonim zapravo vlastito ime za životinju, a ne naziv za životinju (cf. Brozović Rončević, Čilaš Šimpraga, 2008, 37-58).

U lingvistici susrećemo i termin zoosem, kojim se podrazumijeva naziv za životinju u njezinu metaforičkom značenju te za referiranje na čovjeka (cf. Milić, 2013, 197-213). U inozemnoj se frazeologiji za označavanje životinjske sastavnice frazema susreće i termin animalizam. Prema našem shvaćanju pojmovi animalizam i zoonim su u hiperonimsko-hiponimskom odnosu, pri čemu zoonim označava životinjsku sastavnicu u frazemu (primjerice, pas, kokoš, medvjed), a pojam animalizam ima puno šire značenje. Naime, animalizam je prema našem shvaćanju krovni naziv koji može označavati 1) zoonim i zoonimsku pridjevsku izvedenicu, 2) zoosomatizam (primjerice, rep, šapa, griva), ali jednako tako i 3) neku komponentu iz svijeta faune: naziv staništa (primjerice, džungla), nastambe (primjerice, štala), naziv životinjskih proizvoda (primjerice, jaje, med), naziv nekog dodatka ili pribora vezanog za životinju (primjerice, uzda, udica, povo$d a c$ ), ali i 4) onomatopejske glagole (primjerice, cvrkutati) kao i 5) glagole čije je primarno leksičko značenje iz domene životinjskog svijeta 
(primjerice, glodati). Animalistička frazeologija obuhvaća sve frazeme koji sadržavaju jednu od nabrojenih pet vrsta sastavnica, ali jednako se tako animalističkim frazemima smatraju i oni frazemi koji u svom sastavu nemaju ni jednu od ovih sastavnica, ali je zato 6) njihova slika u izravnoj vezi s faunom: primjerice, lizati $<$ svoje $>$ rane.

Upravo je takav princip bio primijenjen prilikom sastavljanja Rječnika hrvatskih animalističkih frazema (RHAF, 2017) skupine autorica predvođenih Ivanom Vidović Bolt. To je prvi hrvatski tematski frazeološki rječnik po svom konceptu jedinstven i u slavenskom svijetu.

\section{Antropomorfizam i zoomorfizam u Rusko-hrvatskome frazeološkom rječniku}

\subsection{Frazeološka građa: principi odabira i glavne značajke}

Poznato je da danas postoje dva osnovna principa odabira frazeološke građe. To su strukturni i semantički princip. Irina V. Zykova $(2019,98)$ tvrdi kako potonji princip odabira „djeluje” na površinskoj razini frazeološkog značenja, pa se tako pri semantičkom principu odabira jezične građe operira s ,rezultatom” procesa frazeologizacije, s ,gotovim značenjem” pri čemu se kulturni koncepti predstavljaju uz pomoć značenjskih sastavnica, tj. semova. „Ako se frazemi odabiru upotrebljavajući semantički pristup, onda se istraživanje realizira od površinske razine prema dubinskoj, od konačnog/aktualnog značenja prema slici frazema, tj. u smjeru «odozgo prema dolje» (top-down)" (Zykova, 2019, 99). Za strukturni princip I. V. Zykova objašnjava kako on „djeluje” na drugoj, tj. na dubinskoj razini frazeološkog značenja. Ističe i da se pri strukturnom pristupu prikupljanja analiziranog korpusa jezičnih znakova operira s raznovrsnim strukturnim sastavnicama - neposrednim predstavnicima kulturnih koncepata - kao ,građevnim” elementima frazeološke slike. To znači da je ,gotova slika” polazišna točka za frazeološku građu prikupljenu upotrebom takva principa. „Slijedi da se jezična građa odabrana po strukturnom principu zapravo proučava iz obrnutog (ili suprotnog) smjera koji se može opisati kao „odozdo prema gore” (bottom-up). Drugim riječima, ako se frazemi odabiru po strukturnom principu, onda se istraživanje realizira od dubinske razine prema površinskoj, tj. od slike prema konačnom/aktualnom značenju" (Zykova, 2019, 99). 
Unatoč činjenici što prihvaćamo integrirani pristup koji primjenjuje Zykova u svojoj monografiji Konceptosfera kulture i frazeologija. Teorija $i$ metode lingvokulturološkog proučavanja (2019) kao najpotpuniji i najsveobuhvatniji, naš je pristup prikupljanja građe u ovom radu samo „odozdo prema gore", i to zbog objektivnih razloga ograničenja teksta.

Prikupljeni korpus u ovom radu obuhvaća ukupno 260 frazema u polazišnom jeziku RHFR. Distribucija prikupljene građe s obzirom na animalističke sastavnice nabrojene ranije u tekstu izgleda na sljedeći način: 1) 152 frazema (59 \%) sadržavaju zoonim (primjerice, бегать как угорелая кошка; змея подколодная; слон на ухо наступил кому), а 19 frazema (7 \%) obuhvaća zoonimsku pridjevsku sastavnicu (primjerice, рядиться в павлиньи (чужсе) перья; с высоть птичьего полёта; лить (проливать) крокодиловы слёзы); 2) ukupno 54 frazema (21\%) iz prikupljene građe imaju zoosomatsku sastavnicu (primjerice, быть в чьей шкуре; в хвосте; гладить по шерсти); 3) 32 frazema (12 \%) sadržavaju neku od sastavnica vezanih za životinjski svijet (primjerice, закон джунглей; грязно где как в хлеву; держать на <коротком> поводке кого); 4) nisu zastupljeni frazemi s onomatopejskim glagolom kao sastavnicom; 5) ni frazemi s glagolima čije je primarno leksičko značenje iz domene životinjskog svijeta; 6) preostala su još 3 frazema (1 \%) sa pozadinskom slikom životinje, no ni jedan ,građevni element” tih frazema nema veze sa životinjskim svijetom (зализать/зализывать <свои> раны; на лету; держать ушки на макушке). Slijedi grafički prikaz navedenih statističkih podataka (il. 1.).

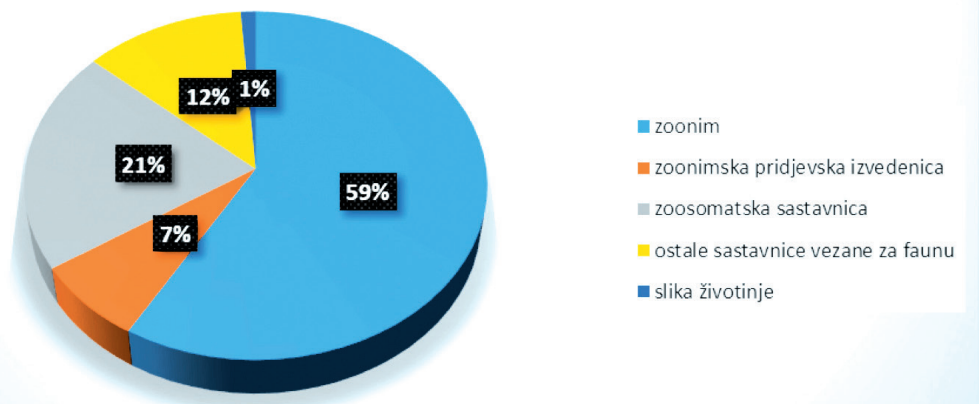

Il. 1. Distribucija prikupljene frazeološke građe s obzirom na animalističku sastavnicu 
Od ukupno 260 prikupljenih ruskih animalističkih frazema njih 178 u ciljnom jeziku ima ekvivalent $s$ animalističkom sastavnicom, pri čemu valja istaknuti da nije uvijek riječ o istoj animalističkoj sastavnici (primjerice, жаба душит кого $\approx$ ima zmiju (kobru) и džepu (novčaniku) tko; бегать как угорелая кошка ₹juriti (trčati i sl.) kao muha bez glave; мухи не обидит кто $\approx$ nе bi ni mrava zgazio tko). Međutim, treba reći da se u RHFR često navodi više hrvatskih značenjskih ekvivalenata, a ako je jedan od navedenih ekvivalenata s animalističkom sastavnicom, mi smo ga u ovoj statistici uzeli u obzir.

U ekscerpiranoj je frazeološkoj građi izdvojeno 65 različitih zoonima, od toga su 3 hiperonima (рыба, птица , скотина). Riječ je o sljedećim zoonimima koje navodimo prema učestalosti uključenosti u frazemе: собака, птица, волк, свинья, муха, слон, рыба, рак, курица, овца, лошадь (конь, конёк), кошка, кот, мышиь. Ostali se zoonimi pojavljuju u jednom ili dvama frazemima. Očekivano je najfrekventniji zoonim собака, domestozoonim prisutan u 14 frazema (primjerice, Вот где собака зарыта [!]; усталый как собака; каждая собака знает кого, что). Pas je najstarija domaća životinja nastanjena po čitavom svijetu. U grčkoj se mitologiji hvali pseća vjernost, ali jednako tako i u djelima srednjovjekovne umjetnosti (Vidović Bolt, 2011, 71-72). Budući da je pas domaća životinja najbliža čovjeku u njegovu suživotu, ne čudi što se sa psom uspoređuju kojekakva stanja čovjeka, a često je zastupljen i u psovkama. Najfrekventniji je zoonim iz skupine divljih životinja волк, kojeg pronalazimo u 7 frazema, primjerice: волк в овечьей шкуре; морской волк; старый (травленный) волк). Vuk je krvoločna i divlja zvijer, pa je i predodžba o njemu u ljudskoj svijesti da je to zla i opaka životinja. Općenito je vuk jedna od središnjih životinjskih figura u mitovima, basnama i pričama (Barčot, 2017, 171, podrobnije o vuku u jezičnoj slici svijeta Hrvata, Rusa i Nijemaca str. 267-269). Medvjed je jedan od osnovnih likova pučke zoologije, a percipira se kao simbol zdravlja, sile, snage (Barčot, 2017, 131). S obzirom na ulogu medvjeda u ruskoj kulturi (podrobnije o medvjedu u jezičnoj slici svijeta Hrvata, Rusa i Nijemaca v. Barčot, 2017, 259-261), očekivali smo veću zastupljenost frazema sa zoonimom медведь, no u analizirani su rječnik uključena svega dva frazema sa spomenutim zoonimom: делить икуру неубитого медведя; медведь на ухо наступил кому. Što se tiče različitih zoosomatizama, 
ukupno ih je 15, a najfrekventniji su хвост (primjerice, висеть на хвосте; поднять/поднимать хвост; укоротить/укорачивать хвост кому) і шкура (primjerice, продажная шкура; быть в чьей шкуре; спасти/спасать свою <собственную> шкуру). Za ostale sastavnice iz faune nismo izdvajali statističke podatke jer se najčešće radi o slaboj učestalosti pojavljivanja. Govorimo, dakle, o frekventnosti pojavljivanja u jednom ili najviše dvama frazemima u analiziranoj frazeološkoj građi.

\subsection{Antropomorfizam vs. zoomorfizam u analiziranoj frazeološkoj građi}

U ovom ćemo se dijelu rada usredotočiti na sve etalone iz prikupljene frazeološke građe. Etalon je sredstvo za mjerenje svojstva i kvalitete predmeta, pojave ili objekta (Маслова, 2001, 44). To je ono čime mjerimo svijet, pa tako etalone u jeziku najčešće susrećemo u obliku ustaljenih poredbi. Na društveno-psihološkoj razini riječ je o normativnim predodžbama o prirodnim i društvenim pojavama, o čovjeku, o njegovim kvalitetama i karakteristikama. Dakle, u središtu našega zanimanja nalaze se ustaljene poredbe kojih je ukupno 67 od 260 prikupljenih frazema, što odgovara gotovo četvrtini frazeološke građe s animalističkom sastavnicom. Zbog ranije spomenutog naglašenog antropocentričnog pristupa prirodi, ovdje polazimo od pretpostavke da će većina detektiranih etalona - u ovom slučaju poredbenih frazema s animalističkom sastavnicom zapravo biti odraz antropomorfizma u jezičnoj slici svijeta govornika ruskoga jezika. Odnosno polazimo od pretpostavke veće zastupljenosti stereotipiziranja životinja u jezičnoj slici svijeta. Stoga ćemo najprije razmotriti one etalone u kojima se životinje mjere ljudskim aršinom te im se pridaju ljudske osobine.

Prvi primjer antropomorfizma u analiziranom korpusu jest predodžba o siromašnom mišu i/ili štakoru, a pronalazimo je u frazemima бедный (беден) как иеерковная мышь і бедный (беден) как иеекквная крыса. Ро svoj se prilici radi o percepciji crkve kao mjesta na kojem nema zaliha hrane, a glodavac nastanjen na tom mjestu posljedično je jadan i siromašan. Idući primjer antropomorfizma vezan je za percepciju slona kao nespretne životinje, što je u izravnoj vezi s frazemom быть (вести себя) как слон 
в посудной лавке. U naivnoj je slici svijeta izvornih govornika ruskoga jezika slon nespretan jer se u takvoj jednoj apsurdnoj situaciji, potpuno neprirodnoj za životinju, slon ne bi mogao (odnosno ne bi znao) kretati pažljivo, onako kako bi se to očekivalo od čovjeka u navedenoj situaciji. Neprimjereno i grubo ponašanje čovjeka uspoređuje se s ponašanjem stoke (вести себя как скотина), što je očiti primjer učitavanja ljudskih osobina životinjama, a ono ima za posljedicu stereotipiziranu percepciju hiperonima stoka i njezina tobože nedoličnog ponašanja. Nadalje, za opis neurednog i/ili prljavog mjesta upotrebljava se etalon u kojem se pojavljuje štala kao secundum comparatum: грязно где как в хлеву. Kada je riječ o prljavštini, sinonim za prljavost u životinjskom svijetu je svinja. I Židovi, i muslimani, i kršćani smatraju svinju nečistom životinjom (Vidović Bolt, 2011, 69). U naivnoj je slici svijeta Rusa potvrda navedenog sljedeći etalon: грязный (грязен) как свинья. Osim sinonima za prljavost svinja je prisutna i u etalonu pijanstva: пьяныий как свинья; напиться как свинья; te u etalonima s temom pretjeranog konzumiranja jela i pića: напиться (нажраться, налакаться) как <последняя> свинья. Glupost se učitava ovnu, što se vezuje uz etalon cмотреть на кого, на что как баран на новые ворота, ali jednako tako i žirafi, odnosno ispravno bi bilo reći da se zbog frazema доходит как до жирафа до кого что, žirafa u naivnoj slici svijeta Rusa doživljava kao glupa životinja, a razlog je tomu tobožnja sporost dotoka informacije do žirafine glave zbog dugačkog vrata. Asocijacije тормоз и тупой na podražaj жираф dokaz su da je stereotipna antropomorfna karakteristika žirafe kao glupe životinje duboko ukorijenjena u svijesti izvornih govornika ruskoga jezika (podrobnije Barčot, 2017, 184-188). Iz frazema жить (сидеть) трутнем proizlaze nerad i društveno parazitiranje koje se učitava trutu. Usporedba zlog čovjeka sa psom (злой как собака) također je rezultat antropomorfizma. Naivna percepcija da riba niti čuje, niti može ispuštati zvukove, krije se u etalonu молчать как рыба. Jednako je tako znanstveno neutemeljena činjenica da noj zabija glavu u pijesak u slučaju opasnosti, što je fiksirano u etalonu спрятать/прятать (положить/класть) голову под крыло (в песок) <как страус>, no upotrebom navedenog poredbenog frazema generira se takva percepcija u jezičnoj slici svijeta. Da se svraka doživljava kao brbljava, dokazano je u opsežnom asocijativnom ispitivanju iz 2012. godine (podrobnije o provedenom istraživanju v. Barčot, 2017, 84-86), 
a objašnjenje zašto se ljudska karakteristika brbljavosti dovodi u vezu s navedenom pticom jest etalon трещать как сорока. Stereotipi su prisutni i u doživljaju mrava i pčele kao marljivih, što je u izravnoj vezi s etalonima трудолюбивый как муравей odnosno трудолюбивый как пчела (пчёлка), a zec je u naivnoj slici svijeta Rusa simbol plašljivosti, koja se generira i potvrđuje upotrebom poredbenog frazema трусливый как заяч (podrobnije Barčot, 2017, 176-184). Isto vrijedi i za ljudsku karakteristiku tvrdoglavosti, koja se pripisuje magarcu, a vezana je za etalon упрямыци как осёл. Kretanje pauna i purana doživljava se kao šepurenje, pa su tako etaloni ходить (щагать) павлином (как павлин) і ходить (шагать) индюком (как индюк) primjeri antropomorfizma.

$\mathrm{O}$ etalonima u kojima se pas dovodi u vezu s umorom (устальій как пёс; усталый как собака) moglo bi se diskutirati je li riječ zaista o antropomorfnom stereotipu ili je secundum comparatum zapravo u službi intenzifikatora.

Uočili smo nekoliko etalona u kojima se opisuje apsurdna situacija koju u prirodi nije moguće pronaći. Riječ je o sljedećim poredbenim frazemima i nespojivim kombinacijama krave i sedla, ribe i kišobrana, psa i pete noge: идёт (подходит) как $<\kappa>$ корове седло $<\kappa>$ кому что; нужен кому как рыбе (рыбке) зонтик; нужен кто, что как собаке пятая нога. Etalon разбираться (смыслить, понимать) в чём как свинья в апельсинах па prvi pogled opisuje apsurdnu situaciju u kojoj se svinje dovode u vezu s narančama, no taj se spoj tobože nespojivog možebitno dade objasniti fiziološkom nemogućnošću kopitara da osjete kiseli okus pa bi tako u slučaju istinitosti navedenog podatka taj etalon zapravo mogao biti primjer zoomorfizma.

Nakon obrade etalona koji su ilustracija antropomorfizma u ispisanoj frazeološkoj građi iz RHFR, slijedi pregled etalona nastalih kao rezultat zoomorfizma, tj. projiciranjem životinjskih osobina na čovjeka. Među izdvojenim etalonima s animalističkom sastavnicom desetak je onih u kojima se neka od fizičkih osobina životinje prenosi na čovjeka, odnosno koristi za opis čovjeka: глаза как у рыси (za opis odličnog vida); здоровый как бык (za opis odličnog općeg zdravstvenog stanja); красный (красен)

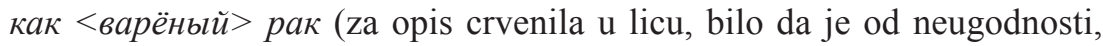
ljutnje ili vrućine); лёгкий как пёрышко і лёгкий как пух (za opis nečije niske težine); толстый (жирный, жирен) как свинья і толстый 
(жирный, жирен) как боров (za opis debele osobe); худой как вобла (za opis mršave osobe); <чёрный (чёрен)> как вороново крыло (za opis obično izrazito crne boje kose); чёрный (чёрен) как жук (za opis crnokose i tamnopute osobe); мокрый как мышь (za opis mokre, ali jednako tako i znojne osobe).

Iduća je podgrupa zoomorfnih etalona vezana za ponašanje životinja koje se prenosi na čovjeka. Psi i mačke su rijetko u harmoničnom suživotu, tako da se etalonom жить как кошка с собакой opisuju loši odnosi među ljudima. Za opis čovjeka koji panično juri, u jezičnoj slici svijeta govornika ruskoga jezika postoji etalon бегать (носиться i sl.) как угорелая кошка. Donosi se, dakle, usporedba s kretanjem pobjesnjele mačke. Suprotno tomu je kretanje puža i kornjače, pa se tako za opis osobe koja se kreće sporo koriste sljedeći etaloni: ташиться (плестись, идти) как улитка; ташиться (плестись, идти) как черепаха. Kako bi se dočaralo obavljanje različitih poslova koji najčešće ne donose pomake naprijed, u naivnoj slici svijeta Rusa postoji etalon вертеться (крутиться, кружиться) как белка в колесе. Riječ je o slici vjeverice koja se vrti u kotaču. Slika psa puštenog s lanca koristi se za opis nečijeg neobuzdanog ponašanja, a fiksirana je zoomorfnim etalonom как с ичепи сорвался кто. Etalon $\langle\kappa a \kappa>$ кость в горле кто, что у кого (кому) паstao je promatranjem situacije u kojoj je kost smetnja u grlu životinji, a u prenesenom značenju predstavlja nekoga tko je velika smetnja. Uz sliku psa vezan je i idući etalon: как (что) собак нерезаных кого. Veliki broj ljudi uspoređuje se s velikim brojem nekastriranih pasa koje nalazimo u skupinama, što i odgovara izvanjezičnoj realnosti. Glad se također povezuje sa psima, ali i vukom -голодный (голоден) как собака; голодный (голоден) как пёс; голодный (голоден) как волк, dok se hladnoća povezuje samo sa psima (замёрзнуть как собака; замёрзнуть как цуциик). Potonja situacija dovodi se u vezu sa psima koji zimske dane i noći provode na otvorenom, bilo da je riječ o napuštenim psima ili onima koji žive u dvorištima privezani na lancu. Neorganizirano, panično kretanje ljudi uspoređuje se s kretanjem stada ovaca - как стадо баранов (овец), a situacija tijesno zbijenih ljudi uspoređuje se sa sardinama u konzervi - как сельди в бочке [набитьл]. Etalon za naporan rad vezan je za konja jer je domaći konj i imao ulogu tegleće i radne životinје: работать (вкальввать) как <ломовая> лошадь. 
U korelaciju s ponašanjem životinja dovodi se i spavanje nekih životinja. Primjerice, svizac velik dio godine provodi u hibernaciji, pa se tako ustalila poredba u službi zoomorfnog etalona: спать (заснуть, уснуть) как сурок; спать (заснуть, уснуть) как суслик. Za razliku od kretanja purana, koje se antropomorfno doživljava kao šepurenje, kretanje patke, odnosno geganje, fiksirano je u zoomorfnom etalonu ходить как утка. Najvažnija sposobnost kameleona, tj. njegova sposobnost da može mijenjati boju kože te se na taj način prilagođavati prirodnom okruženju i pritajiti se, ušla je u jezičnu sliku svijeta i to zahvaljujući etalonu как хамелеон [меняться, менять извет, вести себя]. No time se opisuje čovjekova promjena, primjerice, stavova (ponašanja) radi vlastita probitka, što se percipira kao nešto nepoželjno. Vreva i žamor se uspoređuju s košnicom, što je fiksirano zoomorfnim etalonom как <растревоженный> улей. Ukoliko se rak nađe u plićaku na suhom, to je za njega opasno, pa se tako u jezičnoj slici svijeta govornika ruskoga jezika ustalila poredba как рак на мели kao zoomorfni etalon za opis čovjeka u neprilici, tj. u teškom položaju. Sličnost ponašanja skakavca i čovjeka koji pohlepno poseže za hranom fiksirana je zoomorfnim etalonom наброситься/набрасываться (налететь/налетать) как саранча на что.

Za kraj ovog dijela razmotrit ćemo još tri poredbena frazema koji se zbog inkorporirane kulturološke informacije zapravo ne mogu razmatrati iz perspektive antropomorfizma ili zoomorfizma. Prvi od njih - гол как сокол ${ }^{2}$ - na prvi bi se pogled mogao činiti zoomorfnim etalonom. Jasna Melvinger (1984, 132) razlikuje poredbene frazeme s eksplicitno izraženom osnovom usporedbe od frazema kod kojih je tertium comparationis implicitan. Prema tome bi se u ovom slučaju trebalo raditi o eksplicitno izraženoj osnovi usporedbe, no kako povezati pridjev gol s ovom pticom grabljivicom? Frazeološki etimološki rječnik autorskog trojca A. K. Bierich, V. M. Mokienko i L. I. Stepanova iz 2005. donosi nekoliko objašnjenja etimologije ovog frazema: 1) leksem сокол ne odnosi se na pticu grabljivicu, nego na debeli željezni balvan koji se nekada upotrebljavao za probijanje zidina, a površina mu je metalna, glatka, odnosno „gola”; 2) naziv сокол u srednjem je vijeku označavao top, a radi se o doslovnom

\footnotetext{
${ }^{2}$ Naglasak je ove imenice na drugom slogu, za razliku od naglaska na prvom slogu koji ima imenica сокол u značenju 'sokol'. Dakle, dvije su navedene imenice homografi.
} 
prijevodu francuskog vojnog termina faucon s istim značenjem. Top od funte težine nazivali su falconetto, što u prijevodu s talijanskog odgovara ruskom соколик u prijevodu 'dragi, mili moj'. Na aktivnu je upotrebu analiziranog frazema гол как сокол sa sastavnicom koja označava top od šest funti težine, odnosno сокол, utjecala folklorna simbolika. Сокол је, naime, u narodnoj percepciji iznimno omiljen i hvaljen. Moguća je inačica frazeта гол как сукол, pri с̌ети сукол оznас̌аva spojene kolce koji pridržavaju drvenu ogradu, plot. Ujesen, kada se drvena ograda sruši, propadne, tada ostaju samo ,goli kolci” koji odaju dojam siromaštva, bijede. Moguće je da se u srednjem vijeku riječ сокол aktualizirala pod utjecajem francuskog faucon. Ustaljeni je izraz možebitno nastao prema strukturno-semantičkom modelu ,gol (siromašan) + kao + ptica” u značenju 'jako siromašan', a može se pronaći u ukrajinsko-bjelorusko-rusko-bugarsko-makedonskom arealu. Izraz je eliptična konstrukcija nastala od poslovice гол как сокол, а остёр как бритва (БМС, 2005, 654).

Etimologija frazema как с гуся вода u značenju 'baš me briga za koga, za što' dvojaka je. Prva inačica donosi podatak prema kojem je taj poredbeni frazem zasićen kulturnom informacijom, zbog čega ne bi bio dijelom frazeološke građe koja se obrađuje u ovom radu. Naime, как с гуся вода dio je zaklinjanja koje je vračara izgovarala nad bolesnikom prilikom rituala ozdravljenja: $C$ гуся вода, а с нашего мальчика (девочки) - худоба (болезнь) (RHFR, 2019, 121; БМС, 2005, 172). S druge pak strane, uzme li se u obzir masnoća perja u guske kao razlog nezadržavanja vode na njezinu perju (БMC, 2005, 172-173), ovaj bi frazem mogao biti primjer zoomorfizma.

Posljednji poredbeni frazem koji ćemo spomenuti jest nonacmb/ попадать (попасться, угодить) как кур во щии (в ощии) <куда, во что> u značenju 'naći se / nalaziti se u škripcu; naći se / nalaziti se u nebranom grožđu'. Uključenost sastavnice ruskoga nacionalnog jela šči jamči integriranje kulturološke informacije u ovu jezičnu jedinicu. Prema jednom od tumačenja iz spomenutoga frazeološkog etimološkog rječnika $\kappa y p$ ima staro značenje 'pijetao', a u̧u znači 'seljačku povrtnu juhu'. Budući da je šči nekada označavao posno, vegetarijansko jelo, upravo se time i objašnjava značenje frazema - nemogućnost povezivanja sastavnica кyp i щ̧и (БМС, 2005, 365). Postoje neslaganja oko točnog oblika ovog frazema na način da se inačica sa sastavnicom šči smatra sekundarnom (nonacmь в ощ̧ип > nопасть во щ̧и) (БMC, 2005, 365). 


\section{Obrada antropomorfnih i zoomorfnih frazema u Rusko-hrvatskome frazeološkom rječniku}

U ovom ćemo se dijelu kratko osvrnuti na temu strukture frazeoloških članaka u kojima se obrađuju frazemi koji su predmet interesa ovog istraživanja. Rječnički su članci u Rusko-hrvatskome frazeološkom rječ$n i k u$ - pa tako i oni s animalističkom sastavnicom - koncipirani na način da se najprije navodi naglašena nadnatuknica, potom naglašeni ruski frazem u službi natuknice, nakon čega slijedi objašnjenje značenja ruskoga frazema na hrvatskom jeziku. Poslije definicije slijede primjeri upotrebe. Tu je najčešće riječ o primjerima iz proznih djela ruske književnosti te onima iz ruskih novina i časopisa. Zastupljeni su jednim dijelom i primjeri iz Nacionalnoga korpusa ruskoga jezika (Нацииональный корпус русского языка), no taj je princip u leksikografiji poznat kao corpus-illustrated approach, odnosno riječ je o pristupu u kojem korpus služi za ilustraciju, za razliku od pristupa vođenog korpusom (corpus-driven approach) i pristupa temeljenog na korpusu (corpus-based approach). Naposljetku se navode hrvatski frazemski ekvivalenti. Treba istaknuti da je dio rječničkih članaka obogaćen i etimološkim komentarom na ruskom jeziku.

Postavlja se pitanje nužnosti uključivanja informacije o stereotipiziranju životinja u rječnički članak. Budući da se u frazeografskoj praksi u nas u posljednje vrijeme ustalila upotreba kosih zagrada kao „mjesta” za navođenje pojedinih pragmatičnih informacija o frazemima, to bi eventualno moglo biti rješenje, no smatramo da se u općim frazeološkim rječnicima teško može očekivati uključivanje takvih podataka jer bi se onda po istom kriteriju trebali koncipirati svi rječnički članci, što bi uvelike opteretilo frazeografsku obradu, a u konačnici arhitekturu rječničkog članka. No smatramo da bi to mogla biti ideja za razmatranje za prvi tematski rječnik u nas - RHAF koji bi za neko od novih izdanja mogao razmotriti mogućnost uključivanja ove informacije kojom bi se signalizirali antropomorfizam i zoomorfizam unutar kosih zagrada. 


\section{Umjesto zaključka}

Na kraju bismo naglasili da prikupljena frazeološka građa s animalističkom sastavnicom iz RHFR predstavlja tek $8 \%$ ukupne građe rječnika, a s obzirom da donosi samo dio ukupne ruske animalističke frazeologije, teško možemo donositi sveobuhvatne zaključke o životinjama zastupljenima u tim frazemima te njihovoj percepciji u jezičnoj slici svijeta govornika ruskoga jezika. Za potpuniju analizu i dalekosežnije zaključke valjalo bi razmotriti još animalističke frazeološke građe, potom $u$ istraživanje uključiti i paremiološke jedinice, a u konačnici provesti i ispitivanje izvornih govornika ruskoga jezika asocijativnom metodom, odnosno usporediti postojeće podatke iz Ruskoga rječnika asocijacija (Русский ассойиативный словарь). Tek tada bismo zaista mogli govoriti o percepciji svih 65 životinja uključenih u ovdje detektirane frazeme u naivnoj slici svijeta govornika ruskoga jezika.

Ipak, ono što možemo sa sigurnošću zaključno ustvrditi jest to da se nije potvrdila naša početna pretpostavka o brojnijim frazemima koji su odraz antropomorfizma, već se na analiziranoj građi poredbenih frazema pokazalo da su antropomorfizam i zoomorfizam gotovo podjednako zastupljeni. Dakle, ne možemo reći da se zbog antropocentričnog pristupa prirodi antropomorfizam jače odrazio na jezičnu sliku svijeta govornika ruskoga jezika te da je stereotipiziranje životinja jače izraženo u poredbenim frazemima. Facit je da su etaloni u ekscerpiranoj frazeološkoj građi pokazali da se životinje u jednakoj mjeri mjere ljudskim aršinom, kao što se i ljudi mjere životinjskim aršinom. Svakako bi bilo zanimljivo proširiti ovo istraživanje jer granice RHFR predstavljaju i granice ovog istraživanja, barem što se tiče animalističke frazeologije.

Ostaje nam svima nada u svjetliju budućnost u odnosu na odgojni segment i osvještavanje uloge i značenja životinja u čovjekovu životu, te nada u upravnu i pravnu prevenciju i sankciju svih oblika ponašanja koja su pogubna za životinje i idu na njihovu štetu. Tek će tako izmijenjeno čovjekovo ponašanje dugoročno moći imati utjecaja na smanjenje stereotipiziranja životinja koje se odražava u jezičnoj slici svijeta. 


\section{Literatura}

Barčot, B. (2017). Lingvokulturologija i zoonimska frazeologija. Zagreb: Hrvatska sveučilišna naklada.

Brozović Rončević, D., Čilaš Šimpraga, A. (2008). Nacrt za zoonomastička istraživanja (na primjeru imena konja). „Folia onomastica Croatica” br. 17, str. 37-58.

Melvinger, J. (1984). Poredbeni frazemi. ,Jezik: Časopis za kulturu hrvatskoga književnog jezika" god. 31, br. 5, str. 129-135.

Milić, G. (2013). Pristup zoosemiji u okviru teorije konceptualne metafore i metonimije. ,Jezikoslovlje” br. 14.1, 197-213.

RHAF - Vidović Bolt, I., Barčot, B., Fink Arsovski, Ž., Kovačević, B., Pintarić, N., Vasung, A. (2017). Rječnik hrvatskih animalističkih frazema. Zagreb: Školska knjiga.

RHFR - Fink Arsovski, Ž., Mokienko, V., Hrnjak, A., Barčot, B. (2019). Rusko-hrvatski frazeološki rječnik. Zagreb: Knjigra.

Visković, N. (2009). Kulturna zoologija: Što je životinja čovjeku i što je čovjek životinji. Zagreb: Naklada Jesenski i Turk.

Vidović Bolt, I. (2011). Životinjski svijet u hrvatskoj i poljskoj frazeologiji I. Zagreb: Hrvatska sveučilišna naklada.

Zykova, I. V. (2019). Konceptosfera kulture i frazeologije. Teorija i metode lingvokulturološkog proučavanja. Prev. B. Barčot. Zagreb: Srednja Europa.

Апресян, Ю. Д. (1974). Лексическая семантика. Синонимические средства языка. Москва: Наука.

БМС - Бирих, А. К., Мокиенко, В. М., Степанова, Л. И. (2005). Русская фразеология. Историко-этимологический словарь. Москва: Издательство «Астрель».

Маслова, В. А. (2001). Лингвокультурология. Москва: Издательский центр «Академия».

[Apresjan, J. D. (1974). Leksičeskaja semantika. Sinonimičeskie sredstva jazyka. Moskva: Nauka.

BMS - Bierich, A. K., Mokienko, V. M., Stepanova, L. I. (2005). Russkaja frazeologija. Istoriko-etimologičeskij slovar'. Moskva: Izdatel'stvo: „Astrel'”.

Maslova, V. A. (2001). Lingvokul'turologija. Moskva: Izdatel'skij centr „Akademija”]. 